\title{
PEMETAAN SEBARAN DAERAH ASAL MAHASISWA UNIVERSITAS NEGERI MANADO BERBASIS SISTEM INFORMASI GEOGRAFIS
}

\author{
Nikel Tambengi ${ }^{1}$, Joyce Ch. Kumaat ${ }^{2}$ \\ ${ }^{1}$ Mahasiswa Jurusan Pendidikan Geografi, Fakultas Ilmu Sosial, Universitas Negeri Manado \\ ${ }^{2}$ Dosen Program Studi Geografi, Fakultas Ilmu Sosial, Universitas Negeri Manado \\ e-mail: nikeltambengi@gmail.com
}

\begin{abstract}
The need for information regarding the spatial distribution of the area of origin of students who are currently studying at the Manado State University (UNIMA) is very important because the information built can provide useful input for planning, development, or evaluation. So that the distribution of the areas of origin of students who are studying at UNIMA can be mapped properly, an information system based on Geographical Information Systems (GIS) can be built according to its geographic location. This study aims to create and present information about the spatial distribution of students from UNIMA through GIS. Quantitative type research methods with a spatial analysis approach (spatial analysis) using secondary data. Data analysis techniques through Geographical Information Systems (GIS) to create a digital map of the spatial distribution of student origin using OpenStreetMap and Quantum GIS Zanzibar 3.8.1. The results showed that the spatial distribution of the area from which UNIMA students used GIS, made it easier to present information through digital maps. The information system created can display the distribution data of the student's area of origin, namely the number of students from each province in Indonesia and especially in the form of a distribution map. The largest distribution of student origin came from North Sumatra Province with 1,209, followed by South Sulawesi Province with 893 and North Maluku Province with 650 students.
\end{abstract}

Keywords: Distribution of Students, Mapping, GIS, UNIMA

\begin{abstract}
Abstrak: Kebutuhan akan informasi mengenai sebaran spasial daerah asal mahasiswa yang sedang menempuh pendidikan di Universitas Negeri Manado (UNIMA) sangat penting, karena informasi yang dibangun dapat memberikan masukan yang berguna untuk perencanaan, pengembangan ataupun evaluasi. Agar sebaran daerah asal mahasiswa yang sedang studi di UNIMA dapat dipetakan dengan baik, maka dapat dibangun sistem informasi yang berbasis Sistem Informasi Geografis (SIG) yang sesuai dengan letak geografisnya. Penelitian ini bertujuan untuk membuat dan menyajikan informasi mengenai sebaran spasial asal mahasiswa di UNIMA melalui SIG. Metode penelitian berjenis kuantitatif dengan pendekatan analisis keruangan (spasial analisis) menggunakan data sekunder. Teknik analisis data melalui Sistem Informasi Geografis (SIG) untuk membuat peta digital mengenai sebaran spasial asal mahasiswa menggunakan OpenStreetMap dan Quantum GIS Zanzibar 3.8.1. Hasil penelitian menunjukkan sebaran spasial asal daerah mahasiswa UNIMA menggunakan SIG, mempermudah dalam menyajikan informasi melalui peta digital. Sistem informasi yang dibuat dapat menampilkan data sebaran asal daerah mahasiswa, yakni baik jumlah mahasiswa dari masing-masing provinsi di Indonesia dan terlebih dalam bentuk peta sebaran. Distribusi asal daerah mahasiswa terbanyak berasal dari Provinsi Sumatera Utara berjumlah 1.209, kemudian diikuti Provinsi Sulawesi Selatan berjumlah 893 dan Provinsi Maluku Utara dengan jumlah 650 mahasiswa.
\end{abstract}

Kata Kunci: Sebaran Mahasiswa, Pemetaan, SIG, UNIMA

\section{PENDAHULUAN}

Sistem Informasi Geografis (SIG) adalah salah satu sistem yang dapat digunakan untuk kepentingan strategis, misalnya perencanaan, monitoring dan evaluasi, ataupun kebijakan pembangunan. Berbeda dengan sistem informasi yang lain, Sistem Informasi Geografis (SIG) mempunyai kemampuan analisis spasial, di mana kemampuan tersebut dapat memberikan hasil yang lebih komprehensif dibanding dengan sistem informasi yang hanya berbasis statistik.

Kebutuhan informasi yang terkait dengan 